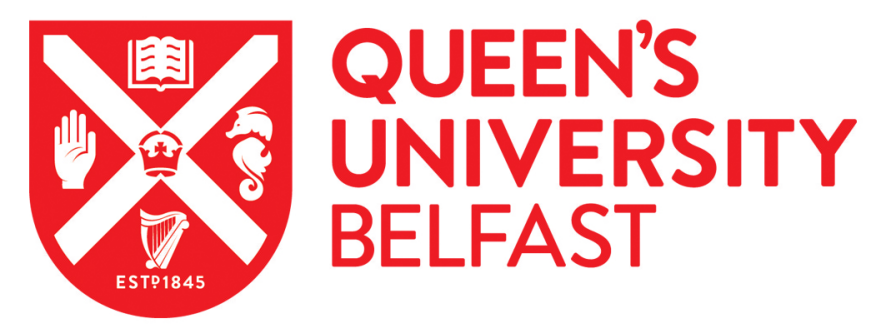

\title{
Administrative Culture
}

MacCarthaigh, M., \& Saarniit, L. (2019). Administrative Culture. In I. Thynne, \& B. G. Peters (Eds.),

Encyclopedia of Public Administration OUP Oxford. https://doi.org/10.1093/acrefore/9780190228637.013.1452

\author{
Published in: \\ Encyclopedia of Public Administration
}

Document Version:

Peer reviewed version

Queen's University Belfast - Research Portal:

Link to publication record in Queen's University Belfast Research Portal

Publisher rights

Copyright 2019 OUP. This work is made available online in accordance with the publisher's policies. Please refer to any applicable terms of use of the publisher.

\section{General rights}

Copyright for the publications made accessible via the Queen's University Belfast Research Portal is retained by the author(s) and / or other copyright owners and it is a condition of accessing these publications that users recognise and abide by the legal requirements associated with these rights.

Take down policy

The Research Portal is Queen's institutional repository that provides access to Queen's research output. Every effort has been made to ensure that content in the Research Portal does not infringe any person's rights, or applicable UK laws. If you discover content in the Research Portal that you believe breaches copyright or violates any law, please contact openaccess@qub.ac.uk. 


\section{$\underline{\text { Administrative Culture }}$}

Muiris MacCarthaigh

Leno Saarniit

\section{Summary}

Administrative culture is an established theme in public administration research and remains subject to a variety of definitions. In this chapter, the various interpretations and uses of administrative culture in academic literature are explored, ranging from national to organisational levels. The ideas of administrative traditions and styles as alternatives to culture are considered, as well as the role culture plays in public sector reform.

\section{Keywords: Culture; Public Administration; Organisational Culture; Administrative Traditions; Styles}

\section{Introduction}

Administrative culture is a widely but loosely used concept in the study of public administration, whose popularity is inversely connected to its precise definition. It is frequently used to explain or contextualise a variety of phenomena in the discipline, ranging from differences in governing styles and policy outcomes between national bureaucracies, to making sense of the informal norms and values that determine the activities of individual public organisations and how they interact with political and non-state interests. It is also occasionally used to characterise a particular 'type' of organisational culture, with features that distinguish it from the private or third sectors. With such myriad uses of the term, as well as related concepts such as administrative style, tradition, and legacies, administrative culture unsurprisingly attracts multiple interpretations as well as its fair share of criticisms as an explanatory tool.

In the Introduction to his volume on European administrative culture, Thedieck (2007: 9) suggests one simple way to understand administrative culture is by considering it as the 
'software' that infuses the 'hardware' of the legal, organizational, economic, financial and sociological aspects of an administrative system. However, as he concedes, this fails to sufficiently grasp the multiple ways in which the concept can and is used. In some contexts, it is an independent variable that helps explain divergence and variety in policy outcomes, while in others it is a dependent variable that attracts experiments and new measurement tools with the aim of producing more sophisticated understanding of its place in public governance. Early scepticism about the study of administrative culture arose in large part due to the absence of adequate methodology as well as uncertainty about how to begin empirical research into the concept. The emergence of such a methodology and tools for inquiry since the 1970s has meant that administrative culture is firmly located in the literature and practice of government, notwithstanding a large variety of definitions and interpretations.

In order to present a full analysis of the concept, this chapter first surveys these various interpretations of administrative culture before turning to examine the emergence of administrative culture within the different streams of cultural research. The key analytical questions in administration culture research - including the issue of sub-cultures - are then presented, as are a number of approaches to studying it within academic public

administration. In the latter half of the chapter, the ideas of administrative traditions and styles as alternatives to culture are considered, and subsequently the role played by administrative culture in public sector reform. A concluding section suggests avenues for future research in the field.

\section{Defining Administrative Culture}

With the proliferation of its use, administrative culture has spawned a variety of interpretations and meanings. Common themes emerging in the literature on administrative 
culture include the problem of defining culture and the level or boundaries to which analysis can be reasonably applied. On the former point Beck, for example, bemoans the ambiguity around "what exactly is or should be meant by "administrative culture" [which] has... restricted the exploration of its theoretical and practical potential in administrative science' (Beck 2007: 29). Perhaps the most detailed survey of the concept is provided by Riggs (2002), who identifies six different manifestations of administrative culture as follows:

1) Aesthetic administrative culture as expressed through public works that salute national achievements and which are focal points for public festivals and ceremonies

2) Administrative culture as the collective product of a well-trained and educated administrative class serving the state

3) Administrative culture as the shared beliefs and practices held by the community of public administrators, and which though part of a broader societal culture, is distinctive from it

4) Administrative culture as representing a distinctive type of organisation that is transnationally recognisable in nature (as bureaucracies increasingly resemble each other across political boundaries arising from common beliefs and practices as well as the flow of ideas between them.)

5) A self-protective administrative culture in which there is a common code of conduct and attitudes shared between members, which may be malign as well as benign.

6) Administrative culture as the search for collective and individual performance improvement. In this sense, what Riggs calls normative administrative culture includes activities that improve the efficiency and quality of public administration through research, education and training. 
Riggs' account of administrative culture brings ideas about traditions, symbols and artefacts

\begin{tabular}{|c|c|c|}
\hline $\begin{array}{l}\text { Administrative Culture } \\
\text { as... }\end{array}$ & & Definitions \\
\hline \multirow{2}{*}{$\begin{array}{l}\text {...the shared beliefs and } \\
\text { practices held by the } \\
\text { community of public } \\
\text { administrators, and } \\
\text { which though part of a } \\
\text { broader societal culture, } \\
\text { is distinctive from it. } \\
\text { (No.3) }\end{array}$} & $\begin{array}{l}\text { Dwivedi (2005: } \\
\text { 20) }\end{array}$ & $\begin{array}{l}\text { '...the modal pattern of values, beliefs, attitudes, and } \\
\text { predispositions that characterize and identify any given } \\
\text { administrative system' }\end{array}$ \\
\hline & $\begin{array}{l}\text { Sommermann } \\
(2015: 5)\end{array}$ & $\begin{array}{l}\text { '...the values, convictions, attitudes and patterns of } \\
\text { behaviour which are characteristic of a given } \\
\text { administrative system' }\end{array}$ \\
\hline \multirow{2}{*}{$\begin{array}{l}\text {...representing a } \\
\text { distinctive type of } \\
\text { organisation that is } \\
\text { transnationally } \\
\text { recognisable in nature } \\
\text { (No.4) }\end{array}$} & $\begin{array}{l}\text { Sharma (2002: } \\
65)\end{array}$ & $\begin{array}{l}\text { '...administrative culture must necessarily be the } \\
\text { culture of administrators, more specifically the culture } \\
\text { of those participants whose activities are restricted to } \\
\text { the administrative environment.' }\end{array}$ \\
\hline & $\begin{array}{l}\text { Henderson } \\
(2004: 236)\end{array}$ & $\begin{array}{l}\text { '...at its most basic, administrative culture may be } \\
\text { thought of as general characteristics of public officials } \\
\text { (i.e. shared values, attitudes, beliefs) - federal, state, } \\
\text { and local.' }\end{array}$ \\
\hline
\end{tabular}

into an administrative context. The importance of these manifestations in public

administration research varies, starting from classical Weberian discussions of bureaucracy as a type of organisation to the influence of organisational culture in developing ethical administration (Lawton et al. 2013: 71-93); to the efficiency and effectiveness discussions that mirror the business administration's approach to organisational culture (Alvesson, 2002: 1); to Pollitt's (2012) discussion of governments as "placemakers", who through social construction of places attribute (cultural) meaning to a physical location.

The most popular definitions of administrative culture reflect a variety of perspectives, but they tend to cluster around Riggs's third and fourth interpretation of the term. Table 1 presents a number of these defintions and how they match with Riggs' typology. |

Table 1: Popular interpretations of administrative culture using Riggs's (2002) typology 
Other definitions are more generic in nature. For example, Schröter and Röber speak of administrative culture as 'a pattern of beliefs, attitudes, and role understandings that prevail among members of the public sector workforce' (2007: 110). And Koci speaks of administrative culture 'as a set of commonly held values, attitudes, and beliefs to which public servants subscribe and are expected to follow' (2007: 256). But to more fully understand the concept of administrative culture, it is necessary to look at how it has emerged as an subject of academic inquiry.

\section{Administrative Culture: Society, Politics, Organisations}

Culture as a variable, as well as object of study, is used in a variety of ways across diverse disciplines, from anthropological interpretations of it as the study of the 'way of life' in a given society, to organisational psychology perspectives that view culture as the collective 'programming' of the mind in a way that is distinctive amongst different groups (Jamil et al. 2013: 900; see also Hofstede 2001). The plurality of contexts and purposes for which culture is used to explain the world around us have one thing in common: that there is no single or universal culture but rather interconnected cultural layers or spheres of overlapping cultural influence that inform and determine the actions of individuals and organisations. These interconnected layers are clearly represented in the research on administrative culture as well, with the analysis not only combining data from societal, political and administrative culture, but also from different administrative levels (from local to international) and from micro to macro levels of research.

The modern study of culture in a public governance context owes much to the work of Almond and Verba (1963), whose five-country analysis titled 'The Civic Culture' proposed 
and popularized the concept of political culture as the key ingredient in successfully connecting citizens to their political institutions. For them, political culture consisted of "attitudes towards the political system and its various parts, and attitudes towards the role of the self in the system" (Almond and Verba, 1963: 13). Contemporaneous work by Riggs $(1961 ; 1964)$ also advocated for a more ‘ecological approach' to comparative public administration research, and like Almond and Verba emphasised the importance of interactions between institutions and their contextual factors, such as social structure, political tradition and administrative culture.

Since then, and reflecting its various interpretations, the relationship between administrative culture and wider political and social cultures have been the source of much contestation. On the one hand some authors view administrative culture as a sub-set of an overall national political culture (Dwivedi, and Gow, 1999; Henderson, 2004; Basu, 2015). Others such as Peters (2010: 35-36) offer a different view, and consider administrative culture as but one of three equal cultures - alongside societal culture and political culture - that influence public administration and its position in society. Developing this idea, Peters asserts that value orientations in society will influence the behaviour of individuals working within formal organisations such as national bureaucracies, as well as the manner in which those organisations are structured and managed.

Administrative culture as a theme within public administration research has been heavily informed by ideas about culture derived from organizational theory (Christensen et al. 2007). Within this broad field, a cultural-institutional perspective views organisations as being 'infused with value beyond the technical requirements of the task at hand' (Selznick 1957: 170) and as such carry distinctive ideas about what problems exist and what the appropriate 
solutions to those problems are. From this perspective, internal forces are more important than external ones in determining what is culturally appropriate behaviour by employees, and the success or otherwise of externally imposed reforms will depend on their compatibility with internal cultural norms and values. And in general, contemporary Western textbooks on public administration have tended to reflect this dual perspective on administrative culture that public organisations exist within an external cultural context that will influence their work (and that of other organisations), and that they each also have a unique internal culture (Pollitt and Bouckaert 2017: 49; Shafritz et al 2017: 70).

This is not to say that organizational culture is fixed or static. For organizational theorists like Allaire and Firsirotu (1984), the cultural system of an organization is one of three inter-related components, interacting with what they call 'the sociostructural system' and 'individual actors'. The cultural system, specifically,

...embodies the organization's expressive and affective dimensions in a system of shared and meaningful symbols manifested in myths, ideology and values and in multiple cultural artefacts (rites, rituals and customs; metaphors, glossaries, acronyms, lexicon and slogans; sagas, stories, legends and organizational lore; logos, design, architecture). This cultural system is shaped by ambient society, the history of the organization and the particular contingency factors impinging upon it; it changes and evolves under the influence of contemporary dominant actors and the dynamic interplay between cultural and structural elements (Allaire and Firsirotu, 1984: 213).

Organizational culture is thus considered a dynamic force, and for organizational management scholars (and consultants), it is possible to mould the internal culture of an organization such as a state bureaucracy - to meet certain ends. In his influential textbook on 
Organizational Culture and Leadership, Schein recognises that 'culture is an abstraction, yet the forces that are created in social and organizational situations deriving from culture are powerful' (2010: 7). He suggests three 'levels' at which culture may be viewed in any given organisation, ranging from artefacts and phenomena that are visible and manifest; to espoused beliefs and values which are the pronounced goals, ideologies and aspirations; to basic underlying assumptions which are the unconscious, taken-for-granted values and beliefs. For an organization to reform its culture, it must recognise how each of these levels manifests itself before it can seek to successfully change its culture.

In more recent years, the organizational psychology work of Hofstede (2001) (and later Hofstede et al 2010) on national cultures and their effects on organisations has also been very influential in the study of administrative culture and reform (cf. Pollitt and Bouckaert 2017). This occurred in large part due to the fact that Hofstede started to measure and allocate scores to an issue that scholars had previously been reluctant to quantify. Developed in 1970s within technology firm IBM, it remains a prominent source for comparative scores on societal cultures despite not specifically focusing on the public sector. According to Hofstede et al. (2010: 4-5),

...culture is always a collective phenomenon, because it is at least partly shared with people who live or lived within the same social environment, which is where it was learned. It is the collective programming of the mind which distinguishes one group of people from another.

Hofstede's original contribution was to quantify dimensions of culture, based on the selfperception of individuals, aggregated to national cultural profiles. 
Updated since (Hofstede et al. 2010), the widely-used model proposes six key dimensions of culture. The first dimension is power distance, that is, the degree to which unequal distribution of power is tolerated. The second dimension, 'uncertainty avoidance', refers to the extent to which members of a culture feel threatened by uncertainty or unknown situations and can tolerate ambiguity. The third is individualism, i.e. the extent to which people feel independent, as opposed to being interdependent as members of larger social collectives. Masculinity versus femininity refers to the dominant values in organizations or societies, and their association with traditional gender roles. The final dimension in the original model is long-term versus short-term orientation, that is, encouraging virtues geared towards future rewards or virtues aimed at satisfying a more immediate need. In the most recent revisions, a sixth dimension - indulgence versus restraint has been added to the initial five. Seen as a complementary dimension to long-term versus short-term orientation, indulgence versus restraint refers to the degree to which the society controls or allows enjoyment of human desires.

Hofstede's model has been praised (cf. Søndergaard (1994: 448-453) as well as criticised (cf. Jones 2007). Its influence in both public and private sector research has brought attention to the interconnectedness of organisational and social/national layers of culture, (Smith, 2002; McSweeney, 2002; Roberts and Boyacigiller, 1984) and it has also been developed further by others, such as the GLOBE project by House et al. (2004). This project provided a replication and extension of the Hofstede study, by adding three additional dimensions, namely: performance orientation, humane orientation and future orientation. 
Although Hofstede's model is not specific to the public sector, its importance to administrative culture should not be underestimated. These dimensions provide contextual data in the analysis of administrative reforms: as Pollitt and Bouckaert (2017: 65) put it, they 'help us understand why what appears to be a similar reform may be very differently received in different cultures. Essentially, the layer of societal culture forms a lens through which different reforms ideas are viewed'. Another example of Hofstede's framework in public administration research is Mouritzen and Svara's (2002) analysis of local government administration and its organisation, especially regarding the power dynamics between elected political officials and appointed civil servants.

Unlike Hofstede et al's. (2010) and House et al. (2004), the work of Jamil (1994) to provide a public sector specific framework should be noted. He proposed that 'public administration as part of the national political system possesses cultural traits that are not well captured by the existing theories of organizational culture' (Jamil 1994: 275). The proposition here was that a study of administrative culture has to incorporate not only the internal context of public administration (such as bureaucrats' attitudes towards work and their place of work), but also the external context, i.e. bureaucracy's relationship to politics and society in general. While organisational cultural theories mostly emphasise interpersonal relationships within organisations, administrative culture emphasises relationships not only within a bureaucracy but outside it as well.

He therefore sought to bridge political and administrative sciences by suggesting three dimensions for the study of administrative culture. These are:

1) Political responsiveness, which maps the politics-administration interface

2) Social responsiveness, which focuses on the (civil) society-administration interface 
3) Cohesiveness, which analyses internal sources of control and the exercise of authority and power within a bureaucracy.

This approach demonstrates most clearly the interaction between different cultural layers, and their importance in understanding administrative culture. Jamil's idea of administrative culture having both external (political and social responsiveness) and internal (cohesiveness) dimensions reflects a general acceptance in the literature of this dual approach to studying culture in a public administration context. However, despite the emergence of this and other frameworks, the basic idea of administrative culture has remained contested.

\section{Approaches to Studying Culture in Public Administration Research}

The study of administrative culture within public administration research has gathered pace since the 1960s. In their 21 st century call for greater recognition of the role of societal culture as an independent variable in public management research, Schedler and Proeller (2007) neatly outline four approaches to studying culture and public sector organisations.

1) The first approach is a sociocultural one. Research adopting this view seeks to explain institutional outcomes via reference to cultural attitudes and traditions. In this vein, culture represents an independent variable which influences outcomes and organisations, structures, and management practices will only be successful and supported by those working within them when they are congruent with the existing culture.

2) In contrast with the sociocultural approach, the second culturalist approach does not treat culture and organisation as separate entities or variables. Rather 
organisations are considered as cultures in and of themselves and are analysed as such. Action, behaviour, and developments within organisations are guided by the meaning and sense-making that members attribute to it. For the mainstream scholarship in public management, culturalist theories have had little significance and impact so far.

3) Perhaps the most influential approach is the neo-institutionalist. There are three established variants to this third approach - historical, sociological and rational (March and Olsen 1989; Christensen et al. 2007). The dominant conception of how organisational culture is established is that informal, institutional norms and values gradually develop through evolutionary, natural developmental processes, and an organisation gradually adapts via internal pressure (brought by members) and external pressure (from its immediate task environment). Unintended and unplanned, these institutionalisation processes create a distinct identity, a 'soul' or culture. In this understanding, culture is something that an institution is. All activity within the institution is underpinned by administrative culture, which creates a foundation of shared meaning, interpretation and values. Institutions are defined as the body of formal and informal rules and regulations, and will have a major impact on social and political outcomes as they pre-determine the behaviour of actors within the organisation or polity.

Much of comparative public administration research has been based on historical institutionalism, which seeks to understand institutions as the product of the unique past history of an organisation (path-dependencies). And so equal causes do not necessarily lead to equal effects, as the outcome of a certain policy will 
depend on the institutional context in which it takes place. Culture is treated as one of several contextual variables having influence on the beliefs, attitudes, and actions of individuals. As a context variable it has substantial influence on the organisational processes and explains varying reform and implementation outcomes.

The second variant of institutionalism - sociological institutionalism - posits that organisations do not necessarily enhance a means-end efficiency, but are the result of interactions associated with the transmission of broader cultural processes (Hall and Taylor 1996). For sociological institutionalists, institutions are not just formal rules, procedures or norms, but also symbols, cognitive scripts, and moral framing that contribute to an organisation's character. Organisations embrace specific institutional forms or practices because the latter are valued within a broader cultural environment. And so organisational change happens because it enhances social legitimacy. For comparative international public administration research, the fact that new organisational practices are adopted to enhance social legitimacy rather than to advance means-end efficiency, points to the importance of understanding the socio-cultural context of reform.

Finally, rational choice institutionalism suggests that a culture or culture system is given and individual actors are shaped by them when formulating preferences and making their decisions. Choices have to be made depending on the combination of cultural forces - administrative, political, social - are at play and which will influence the thought processes of rational actors. Unlike March and Simon's (1993) 'logic of appropriateness' associated with historical and sociological 
institutionalism, rational choice institutionalism tends to be linked to a 'logic of consequences'.

4) The fourth and final approach suggested by Schedler and Proeller is a functionalist one. Work in this perspective posits that culture should be analysed in relation to management challenges and outcomes, i.e. assessing the impact of culture on management outcomes, the influence of culture on change processes, and the determination of certain 'types' of culture and their effect on management. To many, changing the administrative culture is a major task of public management reforms, with the final aim being the achievement of a more efficient and effective public administration.

\section{Analytical Questions in Administration Culture Research}

The development of administrative culture as a field of inquiry influenced by the study of societal, political, and organisational culture, as well as different approaches outlined in two previous sections, have led to several analytical issues that are constantly debated. There are three dominant questions that appear in administrative culture research:

- What is the appropriate level of analysis (from individual officials to macro-level administrative traditions)?

- What level of administration is analysed (local, national, supra-national)?

- Is administrative culture analysed as a dependent or independent variable?

Each of these is considered in turn.

The diversity of definitions and manifestations of administrative culture is reflected in the debate surrounding the level of analysis at which it should be studied. Knill and Grohs (2015) 
offer one way out of this, suggesting that administrative culture is best studied at three different levels:

(1) The micro-level, including the values, roles, and behaviours of individual members of the administration, as well as the attitudes of the general public towards administrations.

(2) The macro-level of administrative traditions.

(3) The meso-level of administrative styles, understood as the standard operating procedures of administrative behaviour and decision-making.

This is different from Keraudren's (1996) proposal that the first level to be studied should be that of the macro (essentially whole-of-government) level, followed by the meso-level (departments, agencies) if macro-level research gives no satisfactory result. An example of a macro national-level interpretation views it as 'the political thinking and idea of officials and political leaders, the consciousness and desire of the officials, the political style of administrative leaders, and the political behaviour pattern represented by public institutions.' (Yun, 2009: 899). At the meso- or organisational level, administrative culture can be viewed as 'the expectations the staff of an organization have about what is 'normal' and 'acceptable' in that organization - 'the way we do things around here' (Pollitt and Bouckaert, 2017: 49).

Alongside most dominant macro- and meso-level typologies of administrative culture that will be discussed in the next sections, there is a vein of inquiry on the micro-level (as Knill and Grohl (2015) classify it), that is concerned with the attitudes and values of individual administrators, and the role this plays in how we conceptualise the broader administrative system. For example, Sharma (2002) argues that an administrative system cannot be analysed without the analysis and understanding of the culture and behaviour of bureaucrats. 
Administrative behaviours infer qualities and characteristic traits, which are constituent parts of administrative culture. Behaviours as such are not synonymous with culture; behaviourpatterns and styles are part of culture. In this perspective, Sharma proposes that an administrative culture is widely understood to convey 'ways of doing or behaving' (2002: 656) and proposes a number of variables, which influence the activities and behavioural patterns of administrators: rationality, autonomy, integrity and transparency. The proposition is that a change in one or more of these variables will change the nature and character of the administrative culture.

In explaining the relationship between micro-, meso-, and macro-levels, the role of 'subcultures' comes into play. Administrative culture can be sometimes supported, sometimes challenged, by two sub-cultures: first, the culture of each individual department or agency of government, with its own mandate, interests, client groups, and major professional and occupational components; second, professional sub-cultures, such as those of accountants, lawyers, economists, engineers, diplomats, and scientists, that cut across organisational boundaries. A composite administrative culture will reflect the values of all its constituent or sub-cultural parts (Dwivedi 2005). On the issue of sub-cultures, Keraudren proposes that a study of administrative sub-cultures must be second to a sufficiently detailed study of administrative cultures because, even if a sub-culture cannot coincide with a culture, it always shares something in common with this culture which makes it subordinate. Without this element, one witnesses not a subculture but a counter-culture or another culture (Keraudren, 1996).

In addition to the analytical levels, there is also a question of levels of administration. In analysing administrative culture, researchers have usually focused on the central bureaucracy 
and top civil servants, profiling their traits and behaviour, and examining the consequences of this for organisational performance (Jabbra and Dwivedi, 2004). Although there are several interesting case studies (e.g. Batac and Carassus, 2009; Gallego-Alvarez et al., 2010; Hulst and van Montfort 2011), administrative culture in local government has received considerably less attention. Rugge (2012: 234-236) has pointed out that the local government traditions that have changed considerably over the past couple of hundred of years, are not sufficiently taken into account. This field of research becomes especially important in case of countries, where state-local government traditions have strong historical legacies.

While administrative culture is mostly studied at the national level, a growing field of scholarship explores the idea of its presence at a supranational level. For example, given political and economic integration as well as extensive policy diffusion and transfer, the transEuropean dimension of administrative culture has also attracted attention (Beck and Thedieck 2008; Thijs et al. 2017). Equally, however, scholars argue that despite the growing density and specificity of legal standards, there is persistent asymmetry in the implementation of EU law in Member States, which draws attention to the role played by administrative culture (Sommerman, 2013; Cini 1997).

The last question deals with administrative culture as a dependent $\mathbf{v}$ independent variable. Within academic public administration, the role and importance of organisational culture is a frequent subject of analysis, and like administrative culture it tends to be treated in one of two ways. On the one hand, organisational cultural values are considered dependent variables that can be manipulated, altered and modified to create the appropriate norm in public sector organisations (e.g. NPM reforms). According to Schedler and Proeller (2007: 189), 'organizations not only possess culture, but also can create culture, and moreover, that the 
right culture is a trigger for efficiency and effectiveness.' In this perspective, therefore, organisational culture is one among several factors that may determine the performance of an organisation. If an organisation's leaders determine that the prevailing culture is not producing intended outcomes, they may resort to reforms to instil an appropriate culture for producing desired goals.

In contrast with this perspective, it may be argued that organisations reflect dominant assumptions, values and norms that cannot be easily manipulated or changed. Since organisations operate and interact with their surrounding environment, they cannot guard against the influx of societal or other values. Consequently, such values are not external to the organisation; they are part of an integrated totality that makes up the organisation as a culture. As such, they are independent variables that need to be controlled for, or taken into account. And so administrative traditions tend to be used as one of the most common independent variables in public administration research.

For the former perspective, leaders choose a course of action based on means-end rationality and alter organisational behaviour at will. In the latter perspective, goals must be compatible with administrative values and organisational culture before they are legitimised, supported, and accepted. The more the goals are attuned to cultural values, the greater the possibility for their successful implementation without opposition (Christensen et al. 2007).

\section{Administrative Culture as Tradition and Style}

In more recent times, the concepts of administrative 'traditions' (cf. Painter and Peters 2010) and 'styles' (Howlett 2004; Howlett and Tosun 2018) have come to be used as synonyms for administrative culture. Each has a different connotation but make important contributions to 
the understanding of how values and behaviours shape the activity and outputs of administrative systems. The idea of an administrative tradition is the first to be examined here.

\section{Administrative Traditions}

For Painter and Peters, an administrative tradition is 'a more or less enduring pattern in the style and substance of public administration in a particular country or group of countries' (2010: 6). As such, administrative traditions provide one of the central explanatory variables in comparative public administration research on administrative development. They are also pointed to as an inhibiting factor to reforms such as NPM or Europeanisation as they dilute, transform or confound them. Developing this, Yesilkagit (2010) argues that from studies on administrative change within comparative public administration, there are two observations: namely that administrative traditions matter, and that administrative traditions strengthen administrative systems' capacity to persist in the face of external shocks to change.

In a European context Pollitt and Bouckaert (2017: 61) and Kuhlmann and Wollmann (2014: 10-11) distinguish between two such administrative traditions - the Continental European Rechtsstaat or civil law model and the Anglo-Saxon 'public interest' system. Each retains distinctive features which are manifest in the legal systems where they are to be found. The broad features of the Rechtsstaat or 'rule of law' system are as follows:

- Following the Roman tradition, there is comprehensive codification of legal rules and the use of administrative courts

- Administrative law is the basic guiding principle for public administration, and so the legality of all administrative actions lies at the core of accountability systems. 
- A deductive and rationalistic administrative culture

- $\quad$ Separation of state and society such that there are both public and private legal spheres - Administrative action is considered to be the implementation of law by means of legal specification. In other words, the role of the bureaucrat is to be one of rule-following and drawing on precedent.

- The dominant values with this tradition are the principle of legality, equality before the law, neutrality of interests and technical expertise.

In contrast, in those states with a common law tradition, where the public interest model is central, there is a more pragmatic attitude towards administrative action and entrepreneurial action within the public administration is valued. Furthermore, in the Anglo-Saxon public interest system:

- There is no separation of public and private law

- The state is of instrumental importance, the focus of activity is the government

- $\quad$ There is not comprehensive codification of legal rules

- The dominant values in this administrative tradition are pragmatism, flexibility and the reconciliation of interests

These traditions have an important bearing not alone on how the administrative system operates, but on who works within it and the requisite skills they have. For example, with the German Rechtsstaat-influenced system, 'lawyers are given priority in recruitment to the higher civil service, by virtue of the legalistic administrative culture" (Kuhlmann and Wollmann 2014: 78). By way of contrast, in the British civil service 'law is usually in the background, rather than the foreground, and many senior civil servants have no special training in its mysteries' (Pollitt and Bouckaert 2017: 61). 
More recently, the polar classification of Rechtsstaat versus public interest administrative tradition has been challenged as unreflective of practice and that in fact most European administrative cultures display mixtures of these features (Demmke and Moilanen 2010). However, it is still the most widely-used classification, that in combination with institutional and structural (and in one case historical) characteristics, forms the basis for public administration classifications. For example, it is used by Kuhlmann and Wollmann (2014 10), who bring out five distinct public administration profiles in the European context, including Continental Europe Napoleonic, Continental European federal, Anglo-Saxon, Scandinavian and the Central-Eastern and South-Eastern European groupings proposed.

This combination of cultural and structural dimensions creates an interesting question about the relationship between the structural and cultural elements. Although the definitions brought out in the previous section tend to focus on the cultural elements (values, symbols, beliefs, norms etc.), Riggs' concept also hints at structural elements (administration as a specific type of organisation). Yesilkagit (2010: 148) states that:

Conceptualising administrative tradition as, on the one hand, ideas and beliefs about the nature of government in a specific national context and, on the other, institutions and structures of government that are created in the past and encoded in a present institutional constellation.

Or as Painter and Peters $(2010,6)$ put it '[t]raditions 'live' both through the thoughts and actions of contemporary actors and also through the 'dead hand' of inherited structures that constrain them in carrying degrees.' 
Although Western understanding of public administration is quite often presented as 'global', several competing approaches can be identified. For example, Drechsler (2018: 19-23) and Jordan and Gray (2011: 349) point to Confucian, Islamic and Buddhist administrative traditions, while Blundo and Le Meur's anthropological work (2008) explores varieties of post-colonial administrative cultures that inhabit African states. Painter and Peters (2010) propose Anglo-American, Napoleonic, Germanic and Scandinavian administrative traditions for understanding the global North, and add to it the Latin American, Postcolonical South Asia and Africa, East Asian, Soviet and Islamicist traditions.

Most of these non-European traditions present an intriguing amalgamation of European (colonial) influences, and local traditions, including religious background and pre-existing local governmental structures and practices (Painter and Peters 2010). The Confucian administrative tradition - 'governing by people' (as opposed to the Roman Rechtsstaat tradition of 'governing by law') (Elliot, 2009: 152), with its emphasis on a highly educated 'mandarinate' class of top administrators to control state affairs, has been particularly influential across Asia (Painter and Peters 2010), despite its considerable westernization (Drechsler 2018: 25). The Soviet system presents a radically different administrative culture, due to its extreme political control and the influence of one particular political ideology imbedded not only in civil service, but also society (Painter and Peters, 2010: 28; Peters 2010, 38). Its influence on post-communist administrative reforms is still debated (cf. MeyerSahling and Yesilkagit 2011). Jordan and Gray (2011:347-249) conclude, that although values such as efficiency, economy, expertise and others 'persist as ethical and practical norms...these terms do not translate similarly across all contexts', reflecting strong historical 
patterns and the importance of religious background (even in seemingly secular traditions, like in Europe).

Painter and Peters suggest four factors that further differentiate between administrative traditions (2010: 6-8):

(1) The administration's relationships with society. The various concepts of state, like the contractual understanding that is characteristic of Anglo-Saxon tradition or a more organic view that is dominant in the Continental Europe, present a different understanding of relationships between societal actors and the bureaucracy. The nature of these relationships may reduce the autonomy of the state and constrain the ability of the public bureaucracy to act with the type of authority at the heart of Weberian conceptions of bureaucracy.

(2) The relationships with political institutions. In essence this concerns the degree of political involvement in the bureaucracy (Peters and Pierre 2004). The relationship with the political class may also influence the level of administrative capacity, the fundamental question being whether technical (merit) or political criteria dominate in administration.

(3) Law vs. Management. This concerns the extent to which public officials are legal figures tasked with identifying the legal foundations of public actions and implementing that law, or whether there is an emphasis on management where the task is to make programs function as efficiently and effectively as possible.

(4) Accountability. Conceptions of accountability differ significantly across social and political cultures. Judicial means of enforcing accountability might be the primary mechanism for controlling a bureaucracy, such as via special administrative courts. The primary alternative to this legalistic form of accountability is to rely on political forums, especially parliaments, as the primary mechanism for its pursuit. 
Painter and Peters concede that clustering by families of administrative 'tradition' and asserting that 'traditions matter' is not to say that there can be no change, or national distinctiveness, nor that all change within a particular national system is always only in one direction or along one preordained path. Furthermore, administrative traditions are not always benign, and may for example inhibit reform or contribute to corruption (Islam 2004; Jamil 2007). For example, in her work on power structures within Mexico, Naijten (2004) identifies that administrative culture may inadvertently sustain corruption as citizens seek to circumvent otherwise labyrinthine bureaucracies. The concept of administrative tradition has also been criticised for being interchanged with state tradition, for referring to both ideas and beliefs about public administration as well as to the structure of a state's administration, and for ambiguity as to whether there is just one national administrative tradition in a polity or several co-existing (i.e. sectoral, national) (Yesilkagit 2010).

\section{Administrative Styles}

In contrast with administrative traditions, an administrative 'style' is, according to Howlett, 'a more or less consistent and long-term set of institutionalized patterns of politicoadministrative relationships, norms and procedures (Howlett, 2003: 475). More recently, Knill et al. speak of administrative styles as 'the standard operating procedures and routines that characterize the behaviour and decision-making of bureaucracies' (2016: 1059). Like culture and tradition, the idea of a national administrative style has been used to explain policy variation in different contexts and are typically conceived of as a dimension of the broader concept of administrative culture. It draws from the idea of a 'national policy style', which Lodge identifies as the 'dominant procedural ambition which reflects the preferred choice of instruments and mirrors normative values in how to achieve accommodation' (Lodge 2012: 552; see also Howlett and Tosun 2018). 
The idea of administrative styles offers a complementary perspective to approaches that confine themselves to the explanatory relevance of institutional structures and formal rules. Under conditions of uncertainty and complexity, administrators and policy-makers develop routines in order to cope with shortages of knowledge, information-processing capacities and time (Simon, 1997). At the level of the organisation, such coping strategies can consolidate into stable patterns of problem-solving behaviour (Knill et al., 2016). Enkler et al. (2017: 367) argue that the concept of administrative style usefully captures these informal procedures and routines that are not officially anchored in the organisation's mandate but are nonetheless crucial for understanding its policy-making capacity.

Similar to administrative traditions, administrative style has both a structural and behavioural component. Thus, while referring to the behaviour of administrative agents, these agents operate within an institutional context that at least in part determines their behaviour. As such, they are situated within a neo-institutional approach to the study of social and political life (Howlett, 2003). Such styles are long-lasting, quasi-permanent arrangements establishing a trajectory of activity that is very difficult to change (i.e. path dependency). Since institutional structures are different, it is to be expected that there will be many different kinds of administrative styles, each style being defined by the set of institutions, rules, traditions and cultures that comprise it. Unsurprisingly, the debate concerning the appropriate level of analysis to which these concepts can be applied reflects that surrounding administrative culture more generally. For example, Howlett (2004) suggests a three-level analysis of administrative style (national, sectoral, departmental) similar to that of Knill and Grohl. And there is also a transnational element to the literature on administrative style, with Knill et al. 
(2016) and Enkler et al. (2017) focusing on style within international public administrations (IPAs).

\section{Administrative Culture and Reform}

By far the most common context within public administration research for administrative culture to be used is that of reform, and the role it plays in facilitating, inhibiting and modifying reform efforts. In the study of comparative public administration reform, administrative culture is typically posited (alongside state structures and politicoadministrative relations) as one of the most influential factors that influence the effectiveness of administrative reform efforts and reform discourse (Kuhlmann and Wollmann 2014: 114115; Pollitt and Bouckaert 2017: 62). This view is shared by others such as Anechiarico who argue that 'administrative culture is produced by a combination of historical, structural, and contemporaneous political factors that shape not only internal rules and customs, but also the predisposition to reform' (Anechiarico, 1998: 17). Similarly, Thedieck proposes that 'administrative culture characterizes...the attitude towards change such as administrative reform.” (Thedieck 2007, p.9). Schick (1998) even argued that most developing countries should not implement public management reforms such as demanded by international organizations, inter alia for reasons of cultural differences.

Despite the contestation over its meaning, culture is universally considered to be an important factor in determining the success or otherwise of public management reform efforts. Research on reform usually elaborates on how societal and organisational cultures define the context for reforms and how culture influences the extent to which administrative reform ideas are taken up in public management practices (Schedler and Proeller 2007). Countries' experiences of reform differ because the different cultural contexts and administrative developments have 
taken different historical paths, leading to differences in administrative norms and values and thus different 'implementation habitats' (Verhoest 2011: 47).

As with the analysis of culture, different dimensions of culture are used to explain reform successes and failures. For example, at an organisational level Bovaird (2007) suggests occupational and sectoral cultures were at play in determining the divergent adoption of public sector reforms within the UK. Taking culture at a national or societal level, Schröter (2000) and Koci (2007) draws on Hofstede's framework to explain differences in reform intensity between Germany and the UK, and within different Swiss language communities respectively.

In one of the earliest attempts to introduce cultural theory into public management reform research, Hood's (1998) 'The Art of the State' applied the 'grid-group' cultural theory of anthropologist Mary Douglas and political scientist Aaron Wildavsky (1982). Hood argued that four management styles exist — which map onto the grid-group categories (hierarchical, egalitarian, individualist, and fatalist way), using it to explain developments in public management reform, such as the spread of NPM around the world. However, Schedler and Proeller (2007: 23) argue that it remains unclear how the move "down-grid/down-group", should happen, and what public managers can do to make this step with their organisations. Moreover, other scholars criticise the crassness of reducing national cultures to two dimensions as in the grid-group theory.

Pollitt and Bouckaert (2017: 46-48) developed a widely used framework for analysing determinants of administrative reform. They identify structural, cultural and functional elements of politico-administrative systems that change infrequently, and therefore can be 
regarded as rather stable characteristics of the environment in a given polity. These elements will also exert a significant influence over both the choice of reforms to be adopted and the feasibility of their implementation as identical (or at least very similar) reforms will develop differently in one national (or sectoral or local) context as compared to another. They suggest five elements that will have a bearing on public management reform efforts: (1) state structure, (2) type of executive government (majoritarian versus consensus), (3) minister/mandarin relations, (4) diversity of policy advice, and 5) the administrative culture. In relation to this latter element, they use the Rechtsstaat or 'public interest' dichotomy, suggesting that the closer a state is to either model will have a bearing on the type of reform that is successfully implemented.

In the case of the much-vaunted New Public Management (NPM) reforms, it has been proposed that the market- and performance-based managerial ideas germane to NPM fell on more fertile ground in the Anglo-Saxon public interest culture where legal and conceptual differences between public and private sectors are unknown and a more 'entrepreneurial' culture exists. In contrast, they were less compatible with the continental European administrative culture where the execution of law remains the predominant administrative activity. Rechtsstaat systems are considered to be 'stickier' and slower to reform than public interest regimes because management change requires changes in the law and, culturally, because senior civil servants who are highly trained in administrative law may find it more difficult than generalists to shift to a 'managerial' or 'performance-oriented' perspective.

Administrative culture has also been one of the key aspects in discussing post-communist transition and administrative reforms. However, the sweeping label of post-communist countries is subject to increased criticism, due to significant differences between the countries 
(e.g. Holmes 2015, Meyer-Sahling 2009). However, at the earliest stages of transition these countries were characterised by the absence of the rule of law that manifested itself in a mismatch between official rules and their implementation, personalistic and discretionary governance, and high levels of politicisation (Meyer-Sahling 2009: 511). Several authors have considered these (administrative) legacies of the communist era as one of the factors (alongside environmental pressures and political actors) that determined not only the outcomes of reforms but also what reform ideas are suitable in the context of post-communist transition (Meyer-Sahling 2009; Verheijen 2007; Drechsler 2005).

These three factors are somewhat similar to some of the elements brought out by Pollitt and Bouckaert (2017). However the way they are interpreted seems more extreme. Communist legacies, whether structural or cultural, are seen from a strongly negative perspective and as an obstacle that needs to be conquered (Verheijen 2007). In short, it is not about tweaking the way things are done, while respecting the existing system, like is the case in many Western European administrative reforms. This negativity is clearly a result of the perceived illegitimacy of communist administration (Drechsler 2005: 99), and essentially means that in the initial transformation, post-communist countries 'cannot draw lessons from their own experience' (Rose 1993: 112). Therefore, environmental pressures are portrayed in a more intense manner, especially through the conditionality of EU accession (Grabbe, 2003) and 'supply-based policy transfer' (Randma-Liiv 2005), meaning that these countries were dependent on what was required and what advice was offered, while lacking expertise to predict the impact of reforms in highly unstable environment. There has been much criticism of the suitability of NPM, the dominant public administration paradigm during 1990s, which was actively promoted in post-communist countries (Drechsler 2005). In addition, there is still no agreement as to whether NPM reforms have been successful in the post-communist 
countries: although Dan and Pollitt (2015) state that they can work, their conclusions are challenged by Drechsler and Randma-Liiv (2016).

More recent research on public management reform has begun to investigate developing or transitional countries. These studies look at why NPM specifically, which proclaimed to have principles of universality, failed to have the same effects as in developed countries. For example, Jabbra and Dwivedi (2004) assess the impact of globalisation on administrative cultures in the Middle East and South Asia. They find that administrative cultures in Middle Eastern countries are still shaped and even dominated by continuing local and indigenous bureaucratic structures and practices, such as nepotism, patron-client relationships, and corruption. This highlights the need to appreciate the importance of indigenous traditions, styles of governance, and administrative cultures that reflect the distinctiveness and complexities of the developing countries' national identities. Indeed a consistent theme in comparative public management research has been a warning against transplanting NPM reforms, which originated mainly within Anglo-Saxon developed countries, straight into other cultural settings.

\section{Conclusions}

Administrative culture continues to be an elusive concept in public administration research and one that is heavily informed by developments in other related disciplines such as management and organisation studies as much as by the political and social sciences. However, there is clearly much scope for research on administrative culture that develops models and frameworks that are specific to government bureaucracies, rather than drawing on national-level frameworks designed for understanding the private sector business or social cultures. And though our understanding of global families of administrative culture has 
enhanced the field, much more work needs to be done to compare and contrast administrative culture cross-nationally. How administrative culture and administrative reforms interact and influence each other is best assessed over time and such longitudinal studies offer much scope for future inquiry.

Several key debates presented here remain relevant to the study of administrative culture, including:

- The 'level' to which the concept applies, e.g. a national, whole-of-government focus or an organisational, departmental one. Typologies and models have been developed for all those levels, and they all remain relevant to the study of administrative culture. In addition, the administrative culture of international organisations is an emerging field of study, whereas local governance is lagging behind.

- The question of convergence versus divergence has been raised through the influence of international promoters of administrative reforms (e.g. EU, OECD, WB, IMF etc.). Despite the seemingly strong international influences, administrative cultures have shown remarkable persistence in maintaining their own identity and filtering reform ideas. But administrative culture also involves the absorption of new ideas, moulding these new ideas to the existing system (and vice versa), while maintaining the core features of that system.

- Administrative culture research is closely connected to the analysis of societal and political culture and uses the main concepts from those fields as well as 
from the field of organisational culture. The main questions concern the openness of a state's administrative system to cultural values from the political realm and society more broadly, and what values make a national administration distinctive. Therefore, different dimensions developed for the analysis of culture (e.g. Hofstede's), are used as independent variables in public administration research to explain the characteristics of administrative culture, administrative reforms and policy styles.

- Similar to public administration research, administrative culture research is mainly of Western origins: the main typology of administrative traditions (Rechtsstaat v common law) is based on European classifications, and does not necessarily take into account the non-Western approaches that have their own understanding of good administration and corresponding ethics.

- The role played by administrative culture in management reform efforts within the public sector is not only an important field of research in a WesternEuropean context, but is also rapidly gaining interest in the context of transitional or developing states. In the case of transitional states the issue of political and administrative discontinuity makes administrative culture research especially interesting in the context of administrative reforms, as the proposed (or imposed) reforms that might lack the support of administrative culture and might therefore fail. This also helps to link questions of administrative culture to non-Western PA research and has enabled to expand typologies to the rest of the world. 


\section{References}

Allaire, Y., and M. E. Firsirotu 1984. 'Theories of organizational culture' Organization Studies 5 (3): 193-226.

Almond and Verba. 1963. The Civic Culture: Political Attitudes and Democracy in Five Nations. Princeton, NJ: Princeton University Press.

Alvesson, M. 2002. Understanding Organizational Culture. SAGE Publications

Beck, J. 2007.'Methods of Research to Explore Administrative Culture' in Thedieck, F. (ed.) Foundations of Administrative Culture in Europe. Baden-Baden; Nomos, pp. 29-36.

Beck, J. and F. Thedieck. 2008. The European Dimension of Administrative Culture. BadenBaden: Nomos.

Basu, A.R. 2015. Decision-making as a Factor in Politico-Administrative Culture' Indian Journal of Public Administration. 61 (5): 139-59.

Batac, J. and D. Carassus. 2009. 'Interactions between control and organizational learning in the case of a municipality: A comparative study with Kloot (1997).' Management Accounting Research, 20, 102-116

Blundo, G. and Le Meur; P-Y. 2008. (eds.) The Governance of Daily Life in Africa: Ethnographic Explorations of Public and Collective Services. Leiden: Brill

Bovaird, T. 2007. 'Triggering Change through Culture Clash: The UK Civil Service Reform Program 1999-2005' in Schedler, K. and Proeller, I. (ed.) Cultural Aspects of Public Management Reforms. Amsterdam: Elsevier: 323-50.

Christensen, T., P. Lægreid, P. G. Roness and K. A. Røvik. 2007. Organization theory and the public sector. Instrument, culture, myth (London, Routledge).

Cini M. 1997. 'Administrative Culture in the European Commission: The Cases of Competition and Environment' in: Nugent N. (eds) At the Heart of the Union. Palgrave Macmillan, London 
Dan, S. and C. Pollitt. 2015. 'NPM Can Work: An optimistic review of the impact of New Public Management reforms in Central and Eastern Europe' Public Management Review, 17 (9), 1305-1332.

Demmke, C. and T. Moilanen. 2010. Civil Services in the EU of 27: Reform Outcomes and the Future of the Civil Service, Peter Lang: Frankfurt am Main.

Douglas, M. and Wildavsky, A. 1982. Risk and Culture. Berkeley, CA: University of California Press.

Drechsler, W. 2005. 'The Re-Emergence of "Weberian" Public Administration after the Fall of New Public Management: The Central and Eastern European Perspective'. Halduskultuur, 6, 94-108.

Drechsler, W. 2018. 'Beyond the Western Paradigm: Confucian Public Administration”, in Bice, S. et al. (eds.) 2018. Public Policy in the Asian Century. (pp. 19-40) International Series on Public Policy.

Drechsler, W. and T. Randma-Liiv. 2016. 'In Some Central and Eastern European Countries, Some NPM Tools May Sometimes Work: A reply to Dan and Pollitt's 'NPM can work'. Public Management Review, 18 (10): 1559-1565.

Dwivedi, O.P. and J.I. Gow. 1999. From Bureaucracy to Public Management: The Administrative Culture of the Government of Canada. Toronto: Broadview Press.

Dwivedi, O.P. 2005. ‘Administrative Culture and Values: Approaches’ in Jabbra, J.G. and Dwivedi, O.P. (eds.) Administrative Culture in a Global Context, Whitby, Ont: de Sitter Publications: 19-36.

Elliot, M. 2009. Emperor Qianlong: Son of Heaven, Man of the World. New York: Longman. Enkler, J.; Schmidt, S.; Eckhard, S. Knill, C. \& Grohs, S. 2017. 'Administrative Styles in the OECD: Bureaucratic Policy-Making beyond Formal Rules' International Journal of Public Administration, 40:8, 637-648, DOI:10.1080/01900692.2016.1186176 
Gallego-Alvarez, I., L. Rodriguez-Dominguez and I.-M. Garcia-Sanchez. 2010. ‘Are determining factors of municipal E-government common to a worldwide municipal view? An intra-country comparison.' Government Information Quarterly, 27, 423-430.

Grabbe, H. 2003. 'Europeanization Goes East: Power and Uncertainty in the EU Accession Process.' In K. Featherstone and C.M. Radaelli (eds.). The Politics of Europeanization. Oxford: Oxford University Press, 303-327.

Hall, P.A. and Taylor, C. R. 1996. 'Political Science and the Three New Institutionalisms', Political Studies, 44 (5): 936-57.

Henderson, K.M. 2004. "Characterizing American public administration: The concept of administrative culture", International Journal of Public Sector Management, 17 (3): 234-250.

Hofstede, G. 1998. 'Attitudes, values and organizational culture: disentangling the concepts', Organization Studies 19(3): 477-492.

Hofstede, G. 2001. Culture’s Consequences: Comparing values, behaviors, institutions and organizations across nations. Thousand Oaks, CA: Sage.

Hofstede, G.; G. J. Hofstede and M. Minkov. 2010. Cultures and Organizations. Software of the Mind ( $3^{\text {rd }}$ edition) New York, McGraw-Hill.

Holmes, L. 2015. "Postcommunist Transitions and Corruption: Mapping Patterns" Social Research, 80 (4) 1163-1186

Hood, C. 1998. The Art of the State: Culture, Rhetoric and Public Management. Oxford: OUP House, R.J., Hanges, P.J., Javidan, M., Dorfman, P. and Gupta, V. (2004) Culture, Leadership, and Organizations: The GLOBE Study of 62 Societies. Thousand Oaks, CA: Sage Publications. 
Howlett, M. 2003. 'Administrative Styles and the limits of administration reform: A neoinstitutional analysis of administrative culture', Canadian Public Administration, 46 (4): 471-94.

Howlett, M. 2004. 'Administrative Styles and Regulatory Reform: Institutional Arrangements and their Effects on Administrative Behavior' International Public Management Review, Vol. 5 (2): 13-35.

Howlett, M. and Tosun, J. 2018. (eds.) Policy Styles and Policy-Making: Exploring the Linkages. London: Routledge

Hulst, J.R. and A.J.G.M. van Montfort. 2011. 'Institutional features of inter-municipal cooperation: Cooperative arrangements and their national contexts' Public Policy and Administration, 27 (2), 121-144.

Islam, N. 2004. 'Sifarish, sycophants, power and collectivism: Administrative culture in Pakistan.’ International Review of Administrative Sciences, 70, 311-330.

Jabbra, J. G. and O.P. Dwivedi 2004. 'Globalization, Governance, and Administrative Culture' International Journal of Public Administration, 27:13-14, 1101-1127, DOI: 10.1081/PAD-200039891

Jamil, I. 1994. 'Administrative culture: a mode of understanding public administration across culture', Research in Urban Policy, Vol. 5, pp. 275-294.

Jamil, I. 2007. Administrative culture in Bangladesh. Dhaka: A.H. Development Publishing House.

Jamil, I.; Askvik, S. \& F. Hossain. 2013. 'Understanding Administrative Culture: Some Theoretical and Methodological Remarks' International Journal of Public Administration, 36 (13), 900-909.

Jones, M.L. 2007. 'Hofstede - Culturally questionable?' Paper presented at Oxford Business \& Economics Conference. Oxford, UK, 24-26 June, 2007 
Jordan, S.R. and P.W. Gray. 2011. The Ethics of Public Administration. The Challenges of Global Governance. Waco, Texas: Baylor University Press

Keraudren, P. 1996. 'In Search of a Culture: Lessons from the past to find a role for the study of administrative culture', Governance, 9 (1): 71-98.

Knill, C., S. Eckhard and S. Grohs. 2016. 'Administrative styles in the European Commission and the OSCE Secretariat: striking similarities despite different organizational settings' Journal of European Public Policy, 23 (7), 1057-1076.

Knill, C. and Grohs, S. 2015. 'Administrative Styles of EU Institutions' in Bauer, M.W. and Trondal, J. (eds.) The Palgrave Handbook of the European Administrative System, (Basingstoke: Palgrave): 93-107.

Koci, M. 2007. 'Culture and Public Management Reforms: A Review and Research Agenda on the Basis of Experiences in Switzerland', in Schedler, K. and Proeller, I. (eds.) Cultural Aspects of Public Management Reforms. Amsterdam: Elsevier: 249-74.

Kuhlmann, S. and H. Wollmann 2014. Introduction to Comparative Public Administration. Administrative Systems and Reforms in Europe. Cheltenham: Edward Elgar.

Lodge, M. 2012. 'Administrative Patterns and National Politics' in Peters, B. G. and J. Pierre (eds.). Sage Handbook of Public Administration. London: Sage: 545-560.

Lawton, A., J. Rayner and K. Lasthuizen. 2013. Ethics and Management in the Public Sector. NY: Routledge.

March, J.G. and J.P. Olsen. 1989. Rediscovering Institutions: The Organizational Basis of Politics. New York: Free Press.

March, J. G. and Simon, H.A. 1993. Organizations (2 ${ }^{\text {nd }}$ edition). Oxford: Blackwell.

McSweeney, B. Hofstede's model of national cultural differences and their consequences: A triumph of faith - a failure of analysis. Human Relations, 2002, 55(1), 89-118. 
Meyer-Sahling, J.-H. 2009. "Varieties of Legacies: A Critical Review of Legacy Explanations of Public Administration Reform in East Central Europe.” International Review of Administrative Sciences 75, 509-528.

Meyer-Sahling, J.-H. and K. Yesilkagit. 2011. "Differential Legacy Effects: Three Propositions on the Impact of Administrative Traditions on Public Administration Reform in Europe East and West.” Journal of European Public Policy 18 (2), 311 322.

Mouritzen, P. E., and J. H. Svara 2002. Leadership at the Apex: Politicians and Administrators in Western Local Governments. Pittsburgh, PA: University of Pittsburgh Press.

Nuijten, M. 2004. 'Between Fear and Fantasy: Governmentality and the Working of Power in Mexico', Critique of Anthropology, 24 (2): 209-30.

Painter, M. and Peters, B.G. (eds.) 2010. Tradition and Public Administration. Basingstoke: Palgrave.

Peters, B.G. 2010. The Politics of Bureaucracy. London: Routledge. (5th ed.)

Peters, B.G. and Pierre, J. (eds.) 2004. The Politicisation of the Civil Service in Comparative Perspective: A Quest for Control. London: Routledge.

Pollitt, C. 2012. New Perspectives on Public Services. Place and Technology. Oxford: OUP Pollitt, C. and G. Bouckaert 2017. Public Management Reform. A Comparative Analysis Into the Age of Austerity. Oxford: OUP.

Randma-Liiv, T. 2005. "Demand and Supply-Based Policy Transfer in Estonian Public Administration.” Journal of Baltic Studies, 36 (4), 467-486.

Riggs, F.W. 1961. The Ecology of Public Administration. London: Asia Publishing House. Riggs, F. 2002. 'Administrative Culture--the Concepts'. International Review of Sociology / Revue Internationale de Sociologie 12 (1): 61-63, DOI: 10.1080/03906700220135327. 
Roberts, K.H. and N.A. Boyacigiller 1984. 'Cross-national Organisational Research: the Grasp of the Blind Men'. Research in Organizational Behaviour, 6, pp. 423-475

Rose, R. 1993. Lesson-Drawing in Public Policy: A Guide to Learning across Time and Space, Chatham House, Chatham, NJ

Rouban, L. 2012. Politicisation of Public Service. in Peters, B. G. and J. Pierre (eds.) 2012. Sage Handbook of Public Administration. (pp. 380-391) London: Sage.

Rugge, F. 2012. Administrative Legacies in Western Europe. in Peters, B. G. and J. Pierre (eds.) 2012. Sage Handbook of Public Administration. (pp. 228-240) London: Sage.

Shafritz, J.M.; Russell, E.W.; Borick, C.P. and A.C. Hyde. 2017. Introducing Public Administration (9 $9^{\text {th }}$ ed.) London: Routledge.

Schedler, K., \& Proeller, I. 2007. Public management as a cultural phenomenon: Revitalizing societal culture in international public management research. International Public Management Review, 8, 186-194. Retrieved from http://www.ipmr.net.

Schein, E. H. 2010. Organisational Culture and Leadership (4th ed.). San Francisco: Jossey Bass.

Schick, A. 1998. Why most developing countries should not try New Zealand reforms. New York, World Bank.

Schröter, E. 2000. 'Culture's Consequences? In Search of Cultural Explanations of British and German Public Sector Reform', in Wollman, H. And E. Schröter (ed.) Comparing Public Sector Reform in Britain and Germany. Dartmouth: Aldershot.

Schröter, E. and Röber, M. 2007. 'Regime Change and Administrative Culture: Role understandings and political attitudes of top bureaucrats from East and West Berlin', American Review of Public Administration, 27 (2): 107-132.

Selznick, P. 1957. Leadership in Administration: A Sociological Interpretation. Berkeley, CA: University of California Press. 
Sharma, R.D. 2002. 'Conceptual Foundations of Administrative Culture - an Attempt at Analysis of some Variables', International Review of Sociology, 12 (1): 65-75.

Simon, H. A. 1997. Administrative Behaviour. New York: The Free Press. (4 ${ }^{\text {th }}$ Ed.)

Smith, P.B. 2002. 'Culture's consequences: Something old and something new', Human Relations, 55 91): 119-135.

Sommermann, K.P. 2013. Towards a Common European Administrative Culture? Jean Monnet Working Paper Series. No. 28/13 (New York: New York University School of Law)

Søndergaard, M. 1994. 'Hofstede's Consequences: A study of of reviews, citations and replications' Organization Studies, 15 (3): 447-456.

Thedieck, F. 2007 'Introduction’ in Thedieck, F. (ed.) Foundations of Administrative Culture in Europe. Baden-Baden; Nomos, pp. 29-36.

Thijs, N.; Hammerschmid, G. and Palaric, E. 2017. A Comparative Overview of Public Administration Characteristics and Performance in EU28, Brussels: European Commission.

Verheijen, A.J.G. 2007. 'Public Administration in Post-Communist States.' In B.G. Peters and J. Pierre (eds.). Handbook of Public Administration. Los Angeles: SAGE Publications: $311-320$.

Verhoest, K. 2011. 'The relevance of culture for NPM' in T. Christensen \& P. Lægreid (Eds.) The Ashgate research companion to new public management (pp. 47-64). London: Ashgate.

Yesilkagit, K. 2010. 'The Future of Administrative Tradition: Tradition as Ideas and Structures' in Painter, M. and Peters, B.G. (eds) Tradition and Public Administration (pp. 145-157). Palgrave Macmillan. 
Yun, E. G. 2009. 'A structuration theory for the transformation of administrative culture for South Korea with the comparative method of huge comparison.' International Journal of Public Administration, 32 (10): 898-920. 